\title{
The Development of the Productuve Creative-Based Choreography Learning Model in Padang State University
}

\author{
Hamsidar, Agusti Efi, Indrayuda
}

\begin{abstract}
This study is aimed to improve students' choreography skills. Since students are still constrained in coming up with ideas, creative imagination in choreography as a result they have minimal choreographic results. The diversity of students' input in the Sendratasik Department is one of the factors causing the low creativity and productivity of students' choreography. It means that the students have different basic abilities of choreography so that they have a minimum of ideas and creativity in learning choreography. Even though the lecturer has used his competence as a choreography lecturer, however in reality the lecturer is more likely and always uses a learning model that has not been able to build students to be more motivated and quick to find ideas and find stimulation of imagination, so they are slow in generating ideas and finding stimulation of the imagination. This type of research is development research or what is called Research and Development (R\&D) with qualitative and quantitative approaches. The Productive Creative-based Choreography Learning Model in this study has produced a valid, practical, and effective model because it has an impact on increasing the choreography ability and learning motivation of students.

Keywords: choreography, creative, productive
\end{abstract}

\section{INTRODUCTION}

Based on the survey data, it can be concluded that as long as students attend choreography class in the semester of 2018, the average student is constrained in generating ideas, finding initial stimuli, stimulating imagination, and creating arable sources or finding motives from exploration results or exploration of the body. Apart from that, they are still slow in preparing the framework for the form of the dance that will be produced from the choreography lectures referred to [14] [15] [16] [17]. Although the lecturer has used his competence as a choreography lecturer, in the learning process, the lecturer is more likely and always uses a learning model that has not been able to build students to be more motivated and to find ideas quickly and stimulation of imagination, on the other hand, they are slow in generating ideas and finding stimulation of imagination [7] [8] [9] [10] [11] [12].

Manuscript received on December 25, 2020.

Revised Manuscript received on January 08, 2021.

Manuscript published on February 28, 2021.

* Correspondence Author

Hamsidar*, Doctoral Program Ilmu Pendidikan, Universitas Negeri Padang, Indonesia

Agusti Efi, Universitas Negeri Padang, Indonesia

Indrayuda, Universitas Negeri Padang, Indonesia

(C) The Authors. Published by Blue Eyes Intelligence Engineering and Sciences Publication (BEIESP). This is an open access article under the CC BY-NC-ND license (http://creativecommons.org/licenses/by-nc-nd/4.0/)
This is because the student learning model tends to be individual, in terms of choreography it can be developed more with group work, which in turn between students will share experiences, and encourage each other in finding ideas and stimulating imagination.

In addition, there has not been anything that stimulates a sense of creativity or pressure from the lecturers so that students have to be creative in finding ideas, expressing new concepts and working patterns in the production of choreography [1] [2] [3] [4] [ 5] [6]. Seeing the above conditions, it is necessary for researchers to develop learning models that can help lecturers to improve development in pedagogical competencies or competencies in learning. Therefore, researchers need to develop a new learning model that is able to answer problems that have been found in previous survey data, one of which is to increase motivation to explore, find stimulation of imagination, or discover initial stimuli for students in choreography learning. Given the high demand for choreography courses, the output of which is a product of a dance work, lecturers in choreography courses must carefully use strategies and relevant learning models that are carried out in the learning process. In the end, students are able to quickly and precisely achieve the target of learning. Therefore, students have been able to produce their dance work products at a right time, and lectures are complete according to the set course achievements.

\section{METHODOLOGIES}

This type of research is development research or what is called Research and Development (R\&D) with qualitative and quantitative approaches. This research was conducted using the 4D model. The research data was taken in the Department of Drama, Dance, and Music, Padang State University. The data analysis of this research was carried out using descriptive statistical analysis techniques and descriptive techniques. Descriptive statistics to analyze student learning achievement and choreography skills, observation sheets, and questionnaires. While the descriptive technique is to analyze the results of interviews, analysis, and field notes.

\section{RESULTS ANALISYS}

\subsection{Product Validity}

Validation of the model is carried out by looking at three aspects, namely aspects of graphics, language, and learning.

Published By:

Blue Eyes Intelligence Engineering

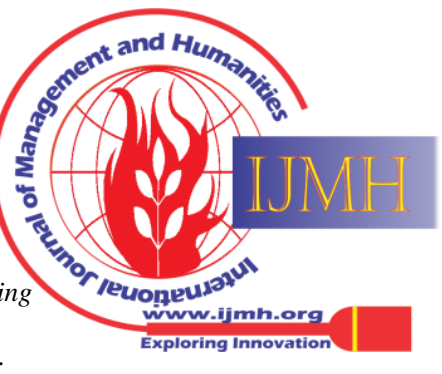


The reliability value of the Model Book Validation Instrument, Student Book, and Lecturer Book for Productive Creative-based Choreography Learning is calculated using the assistance of MS Excel 2007. The following are the results of the reliability calculation of the Productive Creative-based Choreography Learning Model Book Validation Instrument.

Table 1. The validation value of the Choreography Learning Model based on Productive Creative book

\begin{tabular}{|c|c|c|}
\hline Aspect & K & Explanation \\
\hline Supporting theory & 0.73 & Valid \\
\hline Syntax & 0.61 & Valid \\
\hline Social system & 0.61 & Valid \\
\hline Principle of reaction & 0.81 & Very valid \\
\hline Support system & 0.81 & Very valid \\
\hline Instructional impact & 0.75 & Valid \\
\hline $\begin{array}{c}\text { Accompaniment } \\
\text { impact }\end{array}$ & 0.75 & Valid \\
\hline Model implementatin & 0.68 & Valid \\
\hline Average & 0.72 & Valid \\
\hline
\end{tabular}

Based on Table 1, the value of the Productive Creativebased Choreography Learning Model Book is 0.72. These results indicate the level of consistency of the Productive Creative-based Choreography Learning Model Book Validation Instrument is in the valid category.

Table 2. Student book validation scores

\begin{tabular}{|c|c|c|}
\hline Aspect & $\mathbf{k}$ & Explanation \\
\hline Graphic & $\mathbf{0 . 7 8}$ & Valid \\
\hline $\begin{array}{c}\text { Learning } \\
\text { process }\end{array}$ & 0.72 & Valid \\
\hline Language & 0.81 & Very valid \\
\hline Content & 0.75 & Valid \\
\hline Average & 0.76 & Valid \\
\hline
\end{tabular}

Based on Table 2, the value of the productive creative-based choreography learning student book is 0.76 . These results indicate the level of consistency of the Productive Creativebased Choreography Learning Student Book Validation Instrument is in the valid category.

Table 3. The value of the Lecturer Book validation

\begin{tabular}{|c|c|c|}
\hline Aspek & K & Explanation \\
\hline Graphic & 0.84 & Very valid \\
\hline $\begin{array}{c}\text { Learning } \\
\text { process }\end{array}$ & 0.81 & Very valid \\
\hline Language & 0.94 & Very valid \\
\hline Content & 0.89 & Very valid \\
\hline Average & 0.87 & Very valid \\
\hline
\end{tabular}

Based on Table 3, the reliability value of the lecturer book of the Productive Creative-based Choreography Learning Validation is 0.87. These results show the level of consistency of the lecturer book is in the valid category.

3.2. Product Practicality
3.2.1 The results of the practicality test of the model book.

The practicality test (pretest) was carried out on 3 lecturers at Sendratasik UNP Padang. The lecturers were asked to fill out a questionnaire about the model book. The results of the lecturers' responses to the model book can be seen in the following table:

Table 4. The practical value of the model book

\begin{tabular}{|c|c|c|c|c|}
\hline \multirow{2}{*}{ No } & \multicolumn{2}{|c|}{ Pretest } & \multicolumn{2}{c|}{ Posttest } \\
\cline { 2 - 5 } & $\begin{array}{c}\text { Scor } \\
\text { e }\end{array}$ & $\begin{array}{c}\text { Percentag } \\
\text { e }\end{array}$ & Score & $\begin{array}{c}\text { Percentag } \\
\text { e }\end{array}$ \\
\hline $\mathbf{1}$ & 35 & 58.33 & 42 & 70.00 \\
\hline $\mathbf{2}$ & 36 & 60.00 & 43 & 71.67 \\
\hline $\mathbf{3}$ & 35 & 58.33 & 42 & 70.00 \\
\hline Average & 35.33 & 58.89 & 42.33 & 70.56 \\
\hline
\end{tabular}

Based on the data in the table above, it is known that the percentage of the model book pretest score is 58.89 and it is quite practical. Furthermore, based on suggestions from the lecturer, the model book was revised. Some parts that were revised were items number 3,11 , and 12 . Therefore, they were corrected, and a posttest was carried out. The researcher asked the lecturer to fill out a questionnaire about the model book. The results of the model book assessment are 70, 56 and are classified as practical.

3.2.2.The results of the practicality test for lecturers' books The practicality test (pretest) was carried out on 3 lecturers at Sendratasik UNP Padang. Lecturers are asked to fill out a questionnaire about lecturers' books. The results of lecturers 'responses to lecturers' books can be seen:

Table 5. The practical value of lecturers' books

\begin{tabular}{|c|c|c|c|c|}
\hline \multirow{2}{*}{ No } & \multicolumn{2}{|c|}{ Pretest } & \multicolumn{2}{c|}{ Posttest } \\
\cline { 2 - 5 } & $\begin{array}{c}\text { Scor } \\
\text { e }\end{array}$ & Percentage & $\begin{array}{c}\text { Scor } \\
\text { e }\end{array}$ & Percentage \\
\hline $\mathbf{1}$ & 27 & 60.00 & 32 & 71.11 \\
\hline $\mathbf{2}$ & 26 & 57.78 & 32 & 71.11 \\
\hline $\mathbf{3}$ & 27 & 60.00 & 31 & 68.89 \\
\hline Average & 26.67 & 59.26 & 32 & 70.37 \\
\hline
\end{tabular}

Based on the table above, it is known that the percentage of the lecturers' book pretest score is 59.26 and it is quite practical. Furthermore, based on suggestions from the lecturer, the lecturers' book was revised. Some parts that were revised were items number $2,4,10,11$, and 12 . Hence, after being corrected, a posttest was carried out. The researcher asked the lecturer to fill out a questionnaire about the lecturer's book. The results of the lecturer's book assessment are 70, 37 and are classified as practical.

3.2.2.The results of the practicality test of students' book

The first time the researcher did a pretest to students. Furthermore, the researchers divided the activities into two groups. The first group had discussion activities about choreography material. This activity was carried out for 10 meetings for 10 RPP activities. The second activity is a practical activity. This second activity includes 2 lesson plan activities, namely lesson plan 6 and lesson plan 7 . There are details of the activities can be seen in the table below.

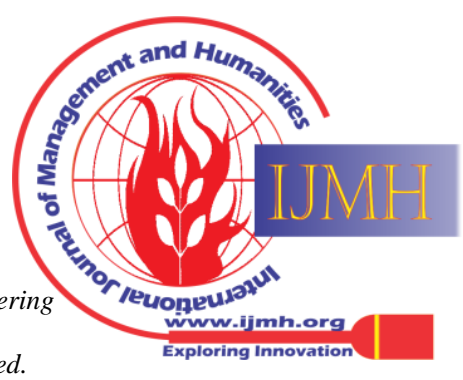


Table 6. Details of choreography learning activities

\begin{tabular}{|c|l|l|}
\hline $\begin{array}{c}\text { Lesson } \\
\text { plan }\end{array}$ & \multicolumn{1}{|c|}{ Date } & \multicolumn{1}{|c|}{ Activies } \\
\hline $1-5$ & $\begin{array}{l}\text { 01 September 2020- 20 } \\
\text { November 2020. }\end{array}$ & $\begin{array}{l}\text { Choreography } \\
\text { Intorudction }\end{array}$ \\
\hline 6 & 25-17 December 2020 & $\begin{array}{l}\text { Creating } \\
\text { choreography }\end{array}$ \\
\hline 7 & 20 December 2020 & $\begin{array}{l}\text { Showing } \\
\text { choreography }\end{array}$ \\
\hline
\end{tabular}

The practicality test (posttest) was carried out on 20 students at Sendratasik, UNP Padang. The students were asked to fill out a questionnaire about the students' book. The results of student responses to students' book can be seen as follows.

Table 7. Students' pretest and posttest results

\begin{tabular}{|c|c|c|c|c|}
\hline \multirow{2}{*}{ No } & \multicolumn{2}{|c|}{ Pretest } & \multicolumn{2}{c|}{ Posttest } \\
\cline { 2 - 5 } & Score & Percentage & Score & Percentage \\
\hline $\mathbf{1}$ & 23 & 51.11 & 32 & 71.11 \\
\hline $\mathbf{2}$ & 25 & 55.56 & 32 & 71.11 \\
\hline $\mathbf{3}$ & 26 & 57.78 & 31 & 68.89 \\
\hline $\mathbf{4}$ & 27 & 60.00 & 31 & 68.89 \\
\hline $\mathbf{5}$ & 23 & 51.11 & 30 & 66.67 \\
\hline $\mathbf{6}$ & 26 & 57.78 & 33 & 73.33 \\
\hline $\mathbf{7}$ & 24 & 53.33 & 34 & 75.56 \\
\hline $\mathbf{8}$ & 25 & 55.56 & 32 & 71.11 \\
\hline $\mathbf{9}$ & 25 & 55.56 & 32 & 71.11 \\
\hline $\mathbf{1 0}$ & 28 & 62.22 & 34 & 75.56 \\
\hline $\mathbf{1 1}$ & 31 & 68.89 & 31 & 68.89 \\
\hline $\mathbf{1 2}$ & 30 & 66.67 & 34 & 75.56 \\
\hline $\mathbf{1 3}$ & 29 & 64.44 & 34 & 75.56 \\
\hline $\mathbf{1 4}$ & 29 & 64.44 & 37 & 82.22 \\
\hline $\mathbf{1 5}$ & 27 & 60.00 & 32 & 71.11 \\
\hline $\mathbf{1 6}$ & 27 & 60.00 & 30 & 66.67 \\
\hline $\mathbf{1 7}$ & 24 & 53.33 & 33 & 73.33 \\
\hline $\mathbf{1 8}$ & 33 & 73.33 & 36 & 80.00 \\
\hline $\mathbf{1 9}$ & 28 & 62.22 & 35 & 77.78 \\
\hline $\mathbf{2 0}$ & 27 & 60.00 & 33 & 73.33 \\
\hline Average & 26.85 & 59.67 & 33 & 72.89 \\
\hline & & & & \\
\hline
\end{tabular}

Based on the table above, it is known that the percentage of the student's book pretest score is 59.67 and it is quite practical. Furthermore, based on suggestions from the students, the students' book was revised. Some of the parts that were revised were items number $2,4,8,10,11,12,18$, and 20. Therefore, after being corrected, a posttest was carried out. The researcher asked the lecturer to fill out a questionnaire about the students' book. The results of the students' book assessment are 72, 89, and are classified as practical.

\section{2. $\quad$ Product Effectiveness}

Here are the details of productive creative-based choreography learning model.

Table 8. Details of Choreography Lessons

\begin{tabular}{|c|ll|l|}
\hline $\begin{array}{c}\text { Lesson } \\
\text { Plan }\end{array}$ & \multicolumn{1}{|c|}{ Date } & \multicolumn{1}{c|}{ Activities } \\
\hline $1-5$ & 25 & November & $\begin{array}{l}\text { Choreography } \\
\text { Intorudction }\end{array}$ \\
\hline
\end{tabular}

\begin{tabular}{|l|l|l|}
\hline 6 & 2 -3 April 2019 & Creating choreography \\
\hline 7 & 9 April 2019 & $\begin{array}{l}\text { Showing } \\
\text { choreography }\end{array}$ \\
\hline
\end{tabular}

After all learning from 1 to 7 is carried out smoothly. The researcher asked the help of a choreography lecturer who taught to fill out a questionnaire on the effectiveness of model book and lecturer book. Then for students, researchers asked students to fill out an effectiveness questionnaire about student book. Following are the results of the normality test.

Table 22. Print out the normality test One-Sample Kolmogorov-Smirnov Test

\begin{tabular}{|cc|r|r|}
\hline \multicolumn{2}{|c|}{$\mathrm{N}$} & Pretest & postes \\
\hline \multirow{4}{*}{ Normal Parameters ${ }^{\mathrm{a}, \mathrm{b}}$} & Mean & 64.5000 & 76.2500 \\
& Std. & 11.5735 & 7.92647 \\
& Deviation & 6 & \\
& Absolute & .194 & .182 \\
Most Extreme Differences & Positive & .194 & .135 \\
& Negative & -.133 & -.182 \\
& .868 & .814 \\
Kolmogorov-Smirnov Z & .438 & .522 \\
Asymp. Sig. (2-tailed) &
\end{tabular}

\section{a. Test distribution is Normal. \\ b. Calculated from data.}

Based on the SPSS output table, it is known that the significance value of asymp.sig (2-tailed) is 0.552, greater than 0.05. Hence, in accordance with the basis of decision making in the Kolmogorov-Smirnov normality test above, it can be concluded that the data is normally distributed. Thus, the assumptions or normality requirements in the regression model have been met.

Table 23. Print out the homogeneity test

Test of Homogeneity of Variances Nilai

\begin{tabular}{|c|c|c|c|}
\hline Levene Statistic & df1 & df2 & Sig. \\
\hline 6.705 & 1 & 38 & .07 \\
\hline
\end{tabular}

Based on the output table "Test of Homogeneity of Variances" above, it is known that the significance value (Sig) of the variable value of Productive Creative-based Choreography Learning is 0.074. Because of the Sig. 0.074> 0.05 , so as the basis for decision making in the homogeneity test above, it can be concluded that the variance of the data on learning outcomes of Productive Creative-based Choreography Learning is the same or homogeneous.

Table 24. Result of the pretest and posttest

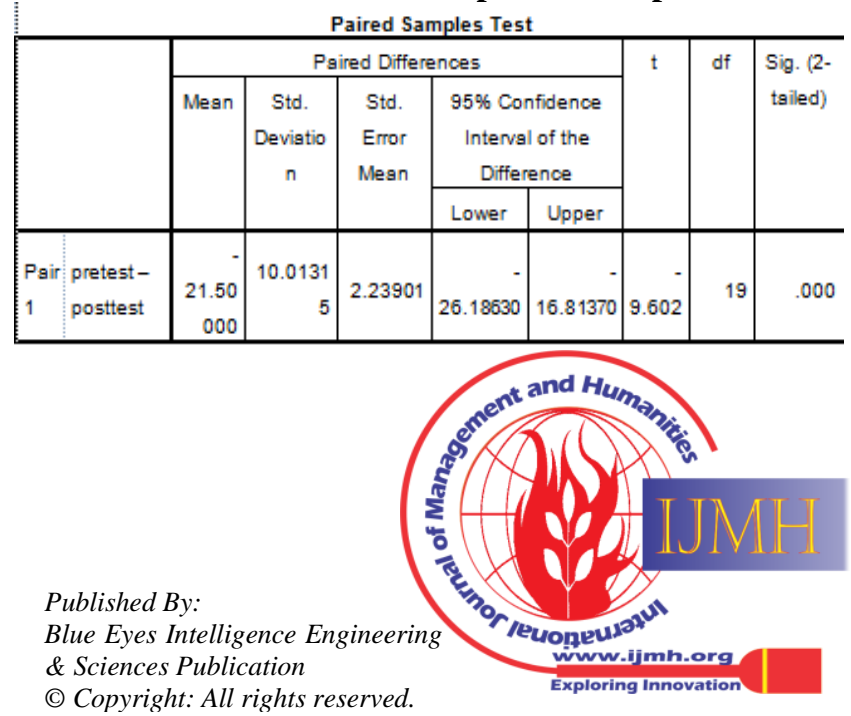


The significant value (2-tailed) of the SPSS output is 0.000 $(\alpha<0.05)$, therefore, Ho is rejected, it can be concluded that there is a difference between the pre-test and post-test scores. Then, based on the average as shown in the excel attachment, it is known that the average post-test score is higher than the pre-test, in which the average post-test score is 76, 25 and the pre-test average value is 64.5 , It can be said that there was an increase in student scores before and after the implementation of the Productive Creative-based Choreography Learning Model.

\section{CONCLUSION}

This research is a research on the development of a productive creative-based choreography learning model along with the system / product support models in the form of lecturer and student books. Based on the discussion of the research results, it can be concluded that 1) Creative Productive-based Choreography Learning Model through the 4D development model has been produced. 2) Productive Creative-based Choreography Learning Model that meets the criteria of validity, practicality, and effectiveness. The model is said to be valid with the characteristics of the suitability of the research model development with the 4D procedure.

The model is said to be practical with the characteristics of ease of use, time suitability, language readability, attractiveness and feasibility of each phase in the model. The model is said to be significantly effective proven to be able to improve writing skills and student motivation.

\section{ACKNOWLEDGMENT}

Thanks to the lecturer promoter, Prof. Agusti Efi and Dr. Indrayuda. His guidance and attention were both extraordinary so that this paper could be completed. Thank you also to the entire academic community of Padang State University. Thank you very much for all your care and academic services.

\section{REFERENCES}

1. Astini, S. M., \& Utina, U. T. (2007). Tari Pendet Seabagai tari Baklihbalihan (Kajian Koreografi)(Pendet Dance as Welcome Dance Coreography Research). Harmonia: Journal Of Arts Research And Education, 8(2).

2. Dick, W; Carey, L\& Carey, James .O. (2009). The systematic design of instruction,(seventh edition).Upper Saddle River, N.J: Pearson

3. Dibia, I W.1999.SeZay<mg Pandang Seni Pertunjukan Bali. Bandung:Masyarakat Seni Pertunjukan Indonesia Volume VIII No.2 Mei-Agustus 2007178 Harmonia Jurnal Pengetahuan Dan Pemikiran Seni

4. Desfiarni, D. (2012). Rangsang Awal sebagai Motivasi dalam Pembelajaran Koreografi di Jurusan Pendidikan Sendratasik. Komposisi: Jurnal Pendidikan Bahasa, Sastra, dan Seni, 10(2).

5. Hartono (2012). Pengembangan Kecerdasan Jamak Dalam Kegiatan Pembelajaran Tari Gajah Melin di TK Negerio Pembina Kabupaten Kendal. Mudra. Jurnal Seni Budaya Vol. 27.Nomor 2 Juli 2012. ISSN 0854-3461.

6. Hartono, H., \& Wantoro, W. (2018). Pembelajaran Koreografi. Imaji: Jurnal Seni dan Pendidikan Seni, 16(2), 128-137.

7. Hera, T. (2018). Rangsang Audio Sebagai Motivasi Pada Penciptaan Karya Tari Tunggu Tubang dalam Pembelajaran Koreografi di Universitas PGRI Palembang. Jurnal Sitakara, 3(1), 58-68.

8. Indrayuda, I. (2015). Tari Tradisional dalam Ranah Tari Populer: Kontribusi, Relevansi, dan Keberlanjutan Budaya. Humanus, 14(2), 144-151.

9. Jazuli, M. (2011). Metode dan Teknik Pengajaran Tari (Method and Technique of Dance Learning). Harmonia: Journal Of Arts Research And Education, 3(2).. Education, Inc.

10. Kocabas, Ö.E. (2012). Using music and musical activities in special education: Developments in Turkey. International online journal of primary education - 2012, volume 1, issue 1.Ege University, Faculty of Education, Department of Educational Sciences, Guidance and Psychological Counseling Program İmir-Turkey.

11. Kulbekova, Aigul K. Dkk. (2016). The methodological framework of occupational training in culture and art high schools of Kazakhstan. International Journal Of Environmental \& Science Education 2016, Vol. 11, No. 12, 5261-5272.

12. Linderman, E.W., \&Herberholz, D.W. (1985). Developing artistic and perceptual awareness: art practice in the elementary clasroom.Dubugue, Lowa: W.C. Brown.

13. Mustafa, M. Nur.(2013). Professional competency differences among high school teachers in Indonesia, Jurnal, International Education Studies; Vol. 6, No. 9; 2013 ISSN 1913-9020 E-ISSN 1913-9039.

14. Purnama, D. S. (2008). Implementasi Model Pembelajaran Kreatif dan Produktif dalam Upaya Peningkatan Mutu Pendidikan Guru. Majalah Ilmiah Pembelajaran, 4(2).

15. Rifai, A. B., \& Setyaningsih, N. H. (2019). Keefektifan Model Multiliterasi Digital dan Model Kreatif-Produktif pada Pembelajaran Menulis Teks Cerita Fantasi. DWIJA CENDEKIA: Jurnal Riset Pedagogik, 3(1), 50-61.

16. Syamsiah, D., \& Salam, R. (2010). Model Pembelajaran Kreatif Produktif Untuk Meningkatkan Kompetensi Memahami Narasi Di Sekolah Dasar. Tesis

17. Surif, S., Wulansari, F. D., \& Fatmawati, S. (2015). Penerapan Model Pembelajaran Kreatif Produktif Dalam Pembelajaran Fisika Materi Gaya. Edu Sains: Jurnal Pendidikan Sains dan Matematika, 3(1).

18. Soemaryatmi. 2010. "Pendidikan Karakter. Melalui Model Pembelajaran Interaktif Mata Kuliah Koreografi”. Makalah. P3AI : ISI Surakarta.

\section{AUTHOR PROFILE}

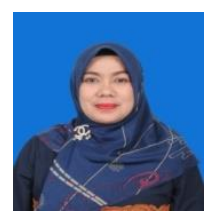

Hamsidar, Hamsidar was born on Lambur, Februari 15 th 1974. She is a doctoral student in the Postgraduate Program starting in 2015 and is currently completing his doctoral education at Padang State University.

Educational background

Primary School Muhammadiyah Kenali Asam at 1986. SMP Swasta YKPP Kota Baru Kota Madya Jambi at 1989.

Madrasah Aliyah Guppi Jambi at 1992.

Akademi Seni Kerawitan Indonesia at 1996.

Pendidikan Guru Kelas Sekolah Dasar Universitas Negeri Padang at 2011.

Pendidikan Seni Budaya Program Pascasarjana Universitas Negeri Padang at 2015.

Job Experiences

2001 TK kuntum mekar.

2002- 2003 SD fransiskus.

2003- 2005 Tk masyithah.

2005- 2014 SD masyithah/smp xaverius.

2011-2015 SMA yayasan pend siswa minang kabau (PSM).

2016- KBRI Kuala Lumpur.

2016- 2021 University Mahidol Bangkok Thailand.

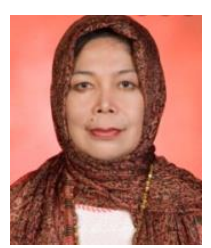

Agusti Efi Marthala, Agusti Efi Marthala is a lecturer at Padang State University. Education S1 Dress Design at IKIP Jakarta. Continuing his master and doctoral education in the field of arts and culture at UKM Malaysia. In 2010 he became professor of Design and Cultural Arts at Padang State University. In addition, he also exists in the world of fashion design, especially batik art in West Sumatra. Padang State University asked him to design a batik shirt motif as a uniform for all lecturers and educational staff at the Padang State University. In addition, several district / city education offices in West Sumatra Province requested his services to design batik clothes as uniforms for elementary, junior high and high school students. He is also a gallery called the Takambang Alam Gallery as a center for the creative work of Minangkabau children of course. 


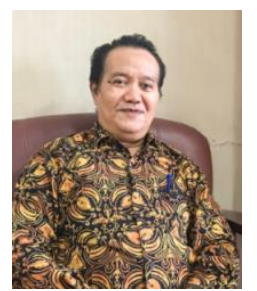

2011.

- $\quad$ Pelatihan Manajemen Seni Pertunjukan LPPM Jakarta at 1999.

- Mengajar lebih kurang 12 SKS persemester.

- Membimbing dan menguji Skripsi dan Tugas Akhir mahasiswa setiap semester 8.

- $\quad$ Pelatihan Juri Nasional Pencak Silat 2002.

- $\quad$ Pelatihan Reviewer Penelitian Desentralisasi (TOT) 2012.

- $\quad$ Pelatihan Instruktur Nasional Kurikulum 2013.

Some articles

- Peran Elit Adat dalam Keberlangsungan Tari Minangkabau ditulis Dalam jurnal Pendidikan dan Kebudayaan DIKTI Vol 5 No. 2 Maret 2009.

- $\quad$ Fenomena Tari Kontemporer Pada Karya Tari Mahasiswa Sendratasik UNP dan STSI Padang Panjang, ditulis dalam Jurnal Pendidikan dan Kebudayaan DIKTI Vol 16 No. 1 Januari 2010.

- Orientasi Spirit Tradisi dalam Karya Tari Kontemporer pada Pembelajaran Koreografi Tari, ditulis dalam Jurnal Bahasa dan Seni FBSS UNP Vol. 9 No. 1 Maret 2008.

- Fungsi Tari Balanse Madam dalam Kehidupan Sosial Masyarakat Nias Bandar Raya Padang Jurnal wacana Seni Universiti Sains Malaysia 2009 Vol 8.

- $\quad$ Penerapan Pendekatan dan Metode yang Relevan dalam Pembelajaran Tari di SMP Negeri 5 Kota Solok Jurnal Bahasa dan Seni Vol 19 No. 2 Tahun 2009.

- Problematika Pewarisan Tari Rantak Kudo di Salido Pesisir Selatan Jurnal Terakreditasi Mudra ISI Denpasar 2013.

- Popularitas Tari Piring Sebagai Identitas Masyarakt Minangkabau Jurnal Panggung STSI Bandung 2013.

- Kegiatan Apresiasi sebagai Sarana Kreativitas Siswa dalam Pembelajaran Seni Tari di SMP negeri 1 Banuhampu Jurnal Bahasa dan Seni FBS UNP 2012

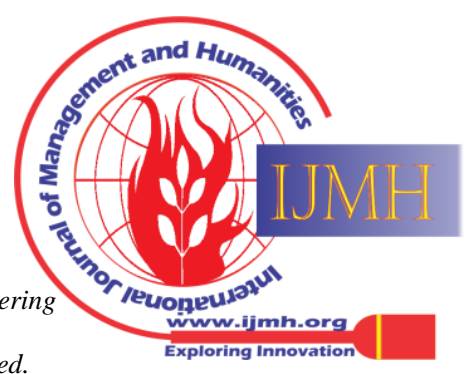

